\title{
Total Mercury in the Night Shark, Carcharhinus signatus in the Western Equatorial Atlantic Ocean
}

\author{
Alexandre Gomes Ferreira ${ }^{1 *}$, Vicente Vieira Faria ${ }^{1}$, Carlos Euardo Veiga de Carvalho ${ }^{1}$, \\ Rosangela Paula Teixeira Lessa ${ }^{2}$ and Francisco Marcante Santana da Silva ${ }^{2}$ \\ ${ }^{1}$ Laboratório de Ciências Ambientais; CBB; Universidade Estadual do Norte Fluminense; Av. Alberto Lamego, \\ 2000, Horto; 28015-620; alexandre@uenf.br; Campos dos Goytacazes - RJ - Brazil. ${ }^{2}$ Laboratório de Dinâmica de \\ Populações Marinhas; Departamento de Pesca; Universidade Federal Rural de Pernambuco; R. Dom Manuel de \\ Medeiros, s/n; Dois Irmãos; 52171-900; Recife - PE - Brazil
}

\begin{abstract}
Mercury is the only element capable to biomagnificate along the food chain, and carnivorous fish tend to accumulate high concentrations of this element. Total mercury in muscle tissue of Carcharhinus signatus sampled along the western equatorial Atlantic Ocean was measured by atomic emission spectrophotometry with ICP/AES. The average total mercury concentrations were consistently greater than the maximum limit for human consumption established by the Brazilian Health Ministry for carnivorous fishes (1000 $\mu \mathrm{g} . \mathrm{kg}-1$ w.w.). Therefore, an average consumption of $0.1 \mathrm{~kg} /$ day of $C$. signatus would result in an average daily ingestion of $174.2 \mu \mathrm{g}$ of $\mathrm{Hg}$, more than five times the $30 \mu \mathrm{g} /$ day intake established by the World Health Organization. In the range of lengths studied, body length could not be used as an indicator of the $\mathrm{Hg}$ contamination degree for C. signatus. Also, sex cannot be considered a determining factor in the total mercury accumulation in $C$. signatus.
\end{abstract}

Key words: Mercury, shark, Carcharhinus signatus, southwestern Atlantic Ocean

\section{INTRODUCTION}

Mercury contamination is generally related to point and non-point sources from natural and anthropogenic causes. Surface runoff, atmospheric deposition and mainly fluvial transport are prominent pathways in the mercury transport from continents to coastal areas (Hanten el al., 1998; Pinho, 1998). Several studies have already shown that mercury can bioaccumulate in muscle tissues of fish, mainly in the methylated form. Mercury concentrations in fish generally present a positive correlation with size and age (Neumann and Ward, 1999; Ward and Neumann, 1999; Lacerda et al., 2000).
Considering that mercury is the only element capable to biomagnificate along the food chain, carnivorous fish tend to accumulate high concentrations of this element. For this reason apex predator fishes may become the main pathway for human contamination through the consumption of contaminated specimens (Monteiro et al., 1996; Paz et al., 1997). In fact, many studies of marine fishes in Brazilian waters have revealed mercury concentrations above $\left(\begin{array}{lll}0.5 & \mu \mathrm{g} \cdot \mathrm{g}^{-1}\end{array}\right)$ the limit for human consumption established by the Brazilian Health Ministry (Aizpurúa et al., 1997; Pinho, op. cit.; Lacerda et al., op. cit.).

\footnotetext{
* Author for correspondence
} 
Although several studies have been carried out on mercury concentration in fish captured in coastal environments, information from oceanic environments is scarce (but, see Pinho, op. cit.). This is possibly due to difficulties in obtaining samples of apex marine predator fishes, such as sharks from oceanic areas. In this study, we were able to analyze mercury concentrations of the Night shark Carcharhinus signatus captured in an oceanic area. The Night shark is one of the most abundant shark species in the western equatorial Atlantic Ocean. It occurs along the outer continental shelf and insular shelves, preferentially at 50 to 100 meters depth. It feeds on benthic bony fishes as scombrids and sea bass (Compagno, 1984; Hazin et al., 2000).

Night shark meat is used for human consumption (Compagno, 1984; Hazin et al., 2000), and may therefore represent an important model for understanding the role of mercury in oceanic environments and the possible intake of mercury from these environments by human populations. The objective of the present work was to determine the total mercury concentration in muscular tissue of $C$. signatus sampled from the western equatorial Atlantic Ocean, and to identify any correlation between mercury levels and shark body length.

\section{MATERIAL AND METHODS}

As part of the Brazilian Program for the Assessment of Living Resources in the Economic Exclusive Zone (REVIZEE), specimens of $C$. signatus were collected from November 1995 to November 1999 from landings of commercial vessels in Natal, Rio Grande do Norte State, Brazil. Sharks were caught in the area made up of deep (Aracati, Dois Irmãos, Fundo, Sirius) and shallow (Pequeno, Leste and Sueste) seamounts with depths at the summits between 38 to $370 \mathrm{~m}$.

Commercial vessels were equipped with $\sim 30 \mathrm{Km}$ Japanese-style multifilament longline gear (Suzuki et al., 1977). On average, each vessel used 970-980 hook.day ${ }^{-1}$, with mainline-set beginning at $\sim 02: 00 \mathrm{~h}$ and ending $\sim$ 06:00 $\mathrm{h}$. The retrieval was started at noon and accomplished by dusk. The Brazilian sardine (Sardinella brasiliensis), flying fish (Cypselurus cyanopterus) and squids (Loligo sp.) were commonly used as bait (Hazin et al., 1998). Landed dressed carcasses of $C$. signatus were identified using the standards described by
Compagno (1984). Each individual's sex and the interdorsal width (IW) (mm), defined as the distance between the posterior base of the first dorsal fin and the anterior base of the second dorsal fin, were recorded.

Approximately $50 \mathrm{~g}$ of muscular tissue of each individual were extracted using a stainless steel scalpel. Samples were kept on ice for transportation to the laboratory, and stored at $-18^{\circ}$ $\mathrm{C}$ until mercury concentration analyses were performed.

Total mercury was determined using a modified version of the methodology described by Bastos et al. (1998), where $1.0 \mathrm{~g}$ of wet weight fish tissue was heated on a hot plate for four hours at $60^{\circ} \mathrm{C}$ with $1 \mathrm{ml} \mathrm{H}_{2} \mathrm{O}_{2}$ and $3 \mathrm{~mL}$ of an acid mixture (1 $\mathrm{H}_{2} \mathrm{SO}_{4}: 1 \mathrm{HNO}_{3}$ ). After cooling, $5 \mathrm{~mL}$ of $\mathrm{KMnO}_{4}$ $5 \%$ were added and the sample was heated again for 30 minutes at $60{ }^{\circ} \mathrm{C}$.

Drops of $12 \% \mathrm{NH}_{2} \mathrm{OH}$.HC were added after cooling and the extracts were then filtered and gauged to $25 \mathrm{~mL}$ with distilled water. The $\mathrm{Hg}$ was measured by atomic emission spectrophotometry with induced coupled plasma (ICP/AES Varian model Liberty II) with vapor generating accessory (VGA 77). The accuracy of the analytical method was verified by analyzing standard certified material - DORM 1 (Squalus acanthias muscular tissue) from the Marine Analytical Chemistry Standard Programs, Canada. The method presented an average recovery of $98.92 \%$.

Total length (TL) was estimated from interdorsal space (IS), using the equation described by Hazin et al. (2000) for the $C$. signatus population in the southwestern equatorial Atlantic Ocean: IS $=-3.46$ +0.26 TL. Mature and immature specimens were identified based on the estimated total length.

A Kolmogorov-Smirnov test was used to test the normality of the total mercury distribution. As the mercury concentrations were not normal distributed $(p<0.05)$, non-parametric statistical analyses were used for data analyses. A regression test was performed to verify the significance of the correlation between the total length and mercury concentration. Furthermore, ANOVA was used to test for a significant correlation between the observed mercury concentration and sex and maturity of $C$. signatus individuals. The significance level adopted on all analyses was $\mathrm{p}<0.05$. 


\section{RESULTS AND DISCUSSION}

The total sample of 38 C. signatus individuals was composed of 19 males ( 9 adults) and 19 females (10 adults). There was no significant difference $(\mathrm{p}=0.274)$ between the mercury concentrations of males and females (Table 1). Also, there was no significant difference between maturity stages $(\mathrm{p}=0.134)$. These results suggested that the intake and retention of $\mathrm{Hg}$ in $C$. signatus in the western equatorial Atlantic Ocean was independent of both sex and maturity (adults or juveniles). Walker (1976) also observed no significant difference in $\mathrm{Hg}$ concentrations between sexes of adult Galeorhinus australis and Mustelus antarcticus from Australian Coast. However, unlike the present study, he observed significant difference in juveniles of these two species.

Table 1 - Total length and mercury concentrations in muscular tissue of different shark species.

\begin{tabular}{|c|c|c|c|c|c|c|c|c|c|}
\hline \multirow{2}{*}{ Species } & \multicolumn{3}{|c|}{ Total Length $(\mathrm{cm})$} & \multirow[b]{2}{*}{$\mathbf{n}$} & \multicolumn{3}{|c|}{ Hg $(\mu \mathrm{g} / \mathrm{kg}$ w.w) } & \multirow{2}{*}{ Studied area } & \multirow{2}{*}{ Source } \\
\hline & Max & Min & Aver. & & Max. & Min. & Aver. & & \\
\hline Carcharhinus signatus (male) & 225 & 139 & 183 & 19 & 3479 & 327 & 1787 & SW Equatorial Atlantic & Present study \\
\hline C. signatus (female) & 244 & 152 & 197 & 19 & 2775 & 1144 & 1697 & SW Equatorial Atlantic & Present study \\
\hline C. signatus & 179 & 129 & - & 06 & 2570 & 1090 & 1777 & Central Brazilian Coast & Pinho 1998 \\
\hline Rhizoprionodon lalandei & 49 & 23 & - & 45 & 280 & 215 & 74.6 & SE Brazilian Coast & $\begin{array}{r}\text { Lacerda et al } \\
2000\end{array}$ \\
\hline Isurus oxyrhinchus & 393 & 165 & - & 90 & 5580 & 590 & 2115 & South African Coast & $\begin{array}{r}\text { Watling et al } \\
1981\end{array}$ \\
\hline Galeorhinus galeus & - & - & 108 & 244 & 4900 & 10 & 640 & SE Australian Coast & Walker 1988 \\
\hline Carcharhinus brevipinna & - & - & 240 & 08 & 610 & 2100 & 1480 & SE Australian Coast & Walker 1988 \\
\hline Carcharhinus brachyurus & - & - & 183 & 07 & 1200 & 230 & 600 & SE Australian Coast & Walker 1988 \\
\hline
\end{tabular}

Specimens of $C$. signatus collected showed reduced size range (Table 1). This could also explain the similar $\mathrm{Hg}$ concentrations between juveniles and adults observed in $C$. signatus, although a more detailed study would be needed in order to verify this hypothesis, including growth rates and length-at-age data.

The similarity of our results to those of Pinho (1998) indicated that $C$. signatus from the central Brazilian Coast and western equatorial Atlantic Ocean had similar rates of $\mathrm{Hg}$ accumulation, though Pinho's small sample size $(n=6)$ reduced confidence in this assumption (Table 1). Indeed, it was also possible that these individuals composed a single population and consequently had the same migration routes and feeding habits, thus sharing environmental conditions and mercury sources throughout its range.

Walker (1988) analyzed mercury concentration of 27 elasmobranch species sampled along the southeastern Australian Continental Shelf at depths greater than $75 \mathrm{~m}$. His results revealed higher $\mathrm{Hg}$ concentrations in deep water pelagic and demersal species (Table 1). According to
Walker, these values could be associated with the predominantly piscivorous feeding habits of the studied species. The $\mathrm{Hg}$ concentrations observed in Australian shark species and Atlantic $C$. signatus corroborated the hypothesis that $\mathrm{Hg}$ concentrations could be related to diet and depth because $C$. signatus was a semi-pelagic species that inhabits environments deeper than $100 \mathrm{~m}$ and feeds mainly on demersal teleost fish.

Lacerda et al. (2000) found lower $\mathrm{Hg}$ concentration values for the coastal shark species Rhizoprionodon lalandei, R. porosus and Mustelus higmani from the north coast of Rio de Janeiro State, Brazil (Table 1). The lower $\mathrm{Hg}$ concentrations could be due to aspects of the three species' life-histories, including living at shallower depths on coastal environments, smaller body size $(23-100 \mathrm{~cm})$, and different feeding habits compared to $C$. signatus. Differences in these characteristics were enough to result in major differences in $\mathrm{Hg}$ accumulation rates in different fish species (Bidone et al., 1997; Doyon et al., 1998). 
The average $\mathrm{Hg}$ concentration in $C$. signatus was $1742 \mu \mathrm{g} / \mathrm{kg}$. This was above the maximum allowed for human consumption of carnivorous fish (1000 $\mu \mathrm{g} / \mathrm{kg}$ w.w.) by the Brazilian Legislation (Brasil, 1975). Of the 38 C. signatus specimens analyzed in the present study, 32 (92\%) had $\mathrm{Hg}$ concentrations above the maximum allowed. Some authors have reported similar results for both freshwater and marine coastal teleost fishes. This showed that the biomagnification phenomenon (e.g. a species from a higher trophic level presented higher $\mathrm{Hg}$ concentrations than the organism from the immediately inferior trophic level), was taking place not only in freshwater but also in marine ecosystems (Kehrig et al, 1998; Bidone et al, 1997). Ingestion of contaminated food has been the most significant $\mathrm{Hg}$ pathway to human populations, and an average ingestion of only $0.1 \mathrm{~kg} /$ day of muscular tissue of the $C$. signatus we sampled could result in a daily intake of $174.2 \mu \mathrm{g}$ of $\mathrm{Hg}$. This value was more than five times the $30 \mu \mathrm{g}$ of $\mathrm{Hg}$ per day maximum intake concentration established by the World Health Organization (WHO). Results of this magnitude have already limited the human consumption of piscivorous species in the USA (Kannan et al., 1998) and Australia (Simpfendorfer and Donohue, 1998).

Higher $\mathrm{Hg}$ concentration in apex predator fish species is recognizably a problem associated with the biomagnification process Marcovecchio et al. (1991). Nevertheless, WHO (1989) observed that fish from non-impacted areas has $\mathrm{Hg}$ concentrations increased with age until, in theory, reaching a "homeostatic equilibrium" between $\mathrm{Hg}$ concentration in the organism (including the depuration capacity) and the bioavailable in the ecosystem. Therefore, more extensive studies with a larger size range, as well as the age determination will add more information in order to clarify the influence of these biotic factors on mercury distribution in C. signatus.

Regression between C. signatus total length and $\mathrm{Hg}$ concentration was low $\left(\mathrm{r}^{2}=0.026\right)$ (Fig. 1), and the correlation between these variables was not significant $(\mathrm{p}=0.068)$. Similarly, an absence of significant correlation between length and $\mathrm{Hg}$ concentration was observed for other six shark species (Squatina argentina, Prionace glauca, Sphyrna sp, Carcharias taurus and Isurus oxyrinchus) from the southeastern Brazilian coast (Morales-Aizpurúa et al., 1999).

Thompson (1985) also observed a lack of correlation between total length and mercury concentration for several fish species distributed along the Tasmanian Continental Shelf. Thompson concluded that use of correlation to estimate mercury content and define human consumption limit for a given species could not be done without proper knowledge of the species biology and the particularities of each environment it inhabited.

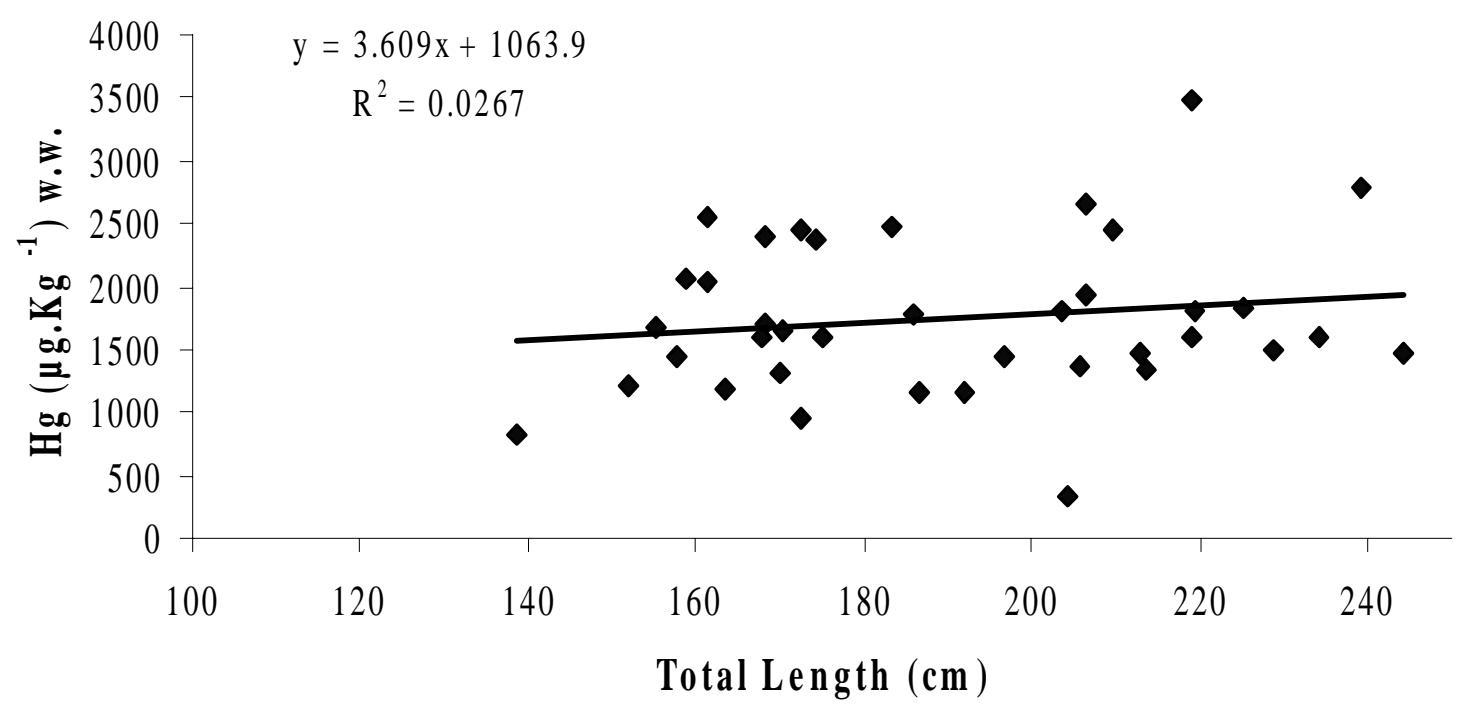

Figure 1 - Total mercury concentration by total length in $C$. signatus from the western equatorial Atlantic Ocean. 
However, mercury concentration in the Mako shark (Isurus oxyrhinchus) from the coast of South Africa revealed a strong correlation between total length and mercury concentration (Watling et al., 1981). In this case, it was recommended that I. oxyrhinchus individuals greater than $2 \mathrm{~m}$ should not be commercially fished for human consumption. Notwithstanding, the same procedure could not be used for $C$. signatus because the mercury distribution was relatively consistent among the different studied lengths, thus not permitting the selection of a specific class size to be avoided.

\section{CONCLUSIONS}

The average total mercury concentrations in $C$. signatus sampled along the western equatorial Atlantic Ocean were consistently greater than the maximum limit for human consumption established by the Brazilian Health Ministry for carnivorous fishes $(1000 \mu \mathrm{g} / \mathrm{kg}$ w.w.). Therefore, an average consumption of just $0.1 \mathrm{~kg} /$ day of $C$. signatus, could result in an average ingestion of $174.2 \mu \mathrm{g} /$ day of $\mathrm{Hg}$, more than five times the daily mercury intake limit of $30 \mu \mathrm{g} /$ day established by the World Health Organization (WHO).

The present study's results indicated that in the range of lengths studied, body length could not be used as an indicator of the $\mathrm{Hg}$ contamination degree for $C$. signatus because there was not a significant difference in $\mathrm{Hg}$ concentration among the studied specimens. Also, sex could not be considered a determining factor in the total mercury accumulation in $C$. signatus, because there was no significant difference between male and female $\mathrm{Hg}$ levels.

\section{ACKNOWLEDGEMENTS}

The authors would like to thank Carla D. Andrade and all REVIZEE Program volunteers from Departamento de Pesca - UFRPE for sampling; Thiago Machado and André Machado for laboratory support and Aspen Garry for critical review of the manuscript. Thanks are due to REVIZEE Program, CNPq, FAPERJ, and FENORTE for financial support.

\section{RESUMO}

O mercúrio (Hg) é o único metal que comprovadamente biomagnifica através da cadeia alimentar, e sendo assim, espécies de peixes predadores tendem a apresentar altas concentrações deste metal. Porções de tecido muscular de $C$. signatus coletados na região oeste equatorial do oceano Atlântico foram submetidas a extração ácida e tiveram a concentração de mercúrio determinada com acessório gerador de vapor a frio acoplado a um ICP-AES. A concentração média de $\mathrm{Hg}$ apresentou valores acima do limite máximo permissível para consumo humano estabelecido pela legislação brasileira (1000 $\mu \mathrm{g} \cdot \mathrm{kg}^{-1}$ de peso úmido). Conseqüentemente, um consumo médio de $0,1 \mathrm{~kg} \cdot \mathrm{dia}^{-1}$ de $C$. signatus resultaria numa ingestão media de $174,2 \mu \mathrm{g}$ de $\mathrm{Hg}$, mais de cinco vezes o consumo máximo de 30 $\mu$ g.dia ${ }^{-1}$ estabelecido pela Organizacao Munidal da Saúde. Dentro das classes de tamanho analisadas, o comprimento total não pode ser utilizado como indicador do grau de contaminação por mercúrio em $C$. signatus. Ainda, o sexo não pode ser considerado um fator determinante na acumulação total de mercúrio em $C$. signatus.

\section{REFERENCES}

Aizpurúa, I. C. M.; Tenuta-Filho, A.; Sakuma, A. M. and Zenebon, O. (1997), Use of cysteine to remove mercury from shark muscle. International Journal of Food Science and Technology., 32, 333-337.

Bastos, W. R.; Malm, O.; Pfeiffer, W. C.; Cleary, D. (1998), Establishment and analytical quality control of laboratories for $\mathrm{Hg}$ determination in biological and geological samples in the Amazon, Brazil. Ciência e Cultura, 50 : (4), 255-260.

Bidone, E. D.; Castilhos, Z. C.; Cid de Souza, T. M. and Lacerda, L. D. (1997), Fish contamination and human exposure to mercury in the Tapajós River Basin, Pará State, Amazon, Brazil: a screening approach. Bulletin of Environmental Contamination and Toxicology, 59, 194-201.

Brasil (1975), Diário Oficial da União, Resolução $n$. $18 / 75$.

Compagno, L. J. V. (1984), FAO species catalogue vol 4. Sharks of the world. An annotated and illustrated catalogue of shark species known to date. Part 2. FAO Fisheries Synopsis, 4 : (125), 251-655. 
Doyon, J. F.; Schetagne, R. and Verdon, R. (1998), Different mercury bioaccumulation rates between sympatric populations of dwarf and normal Lake Whitefish (Coregonus clupeaformis) in the La Grande complex watershed, James Bay, Québec. Biogeochemistry, 40, 203-216.

Hanten, R. P.; Neumann, R. M. and Ward, S. M. (1998), Relationships between concentrations of mercury in Largemouth Bass and physical and chemical characteristics of Connecticut Lakes. Transactions of the American Fisheries Society, 127, 807-818.

Hazin, F. H. V.; Zagaglia, J. R., Broadhurst, M. K.; Travassos, P. E. P., and Bezerra, T. R. Q. (1998), Review of a small-scale pelagic longline fishery off northeastern Brazil. Marine Fisheries Review, 60, 1-8.

Hazin, F. H. V.; Lucena, F. M.; Souza, T. S. A. L.; Boeckman, C. E.; Broadhurst, M. K. and Menni, R. C. (2000), Maturation of the Night Shark, Carcharhinus signatus in the southwestern equatorial Atlantic Ocean. Bulletin of Marine Science, 66 : (4), 173-185.

Kannan, K.; Smith Jr., R. G.; Lee, R. F.; Windom, H. L.; Heitmuller, P. T.; Macauley, J. M. and Summers, J. K. (1998), Distribution of total mercury and methyl mercury in water, sediment and fish from south Florida estuaries. Archives of Environmental Contamination and Toxicology, 34, 109-118.

Kehrig, H. A.; Malm, O. and Moreira, I. (1998), Mercury in a widely consumed fish Micropogonias furnieri (Demarest, 1823) from four main Brazilian estuaries. The Science of the Total Environment, 213, 263-271.

Lacerda, L. D.; Paraquetti, H. H. M.; Marins, R. V.; Rezende, C. E.; Zalmon, I. R.; Gomes, M. P. and Faria, V. (2000), Mercury content in shark species from the southeastern Brazilian Coast. Revista Brasileira de Biologia, 60 : (4), 571-576.

Marcovecchio, J. E.; Moreno, V. J. and Pérez, A. (1991), Metal accumulation in tissues of sharks from the Bahía Blanca Estuary, Argentina. Marine Environmental Research, 34, 263-274.

Monteiro, L. R.; Costa, V.; Furness, R. W. and Santos, R. S. (1996), Mercury concentrations in prey fish indicate enhanced bioaccumulation in mesopelagic environments. Marine Ecology Progress Series, 141, 21-25.

Morales-Aizpurúa, I. C.; Tenuta-Filho, A.; Sakuma, A. M. and Zenebon, O. (1999), Mercúrio total em cação comercializado em São Paulo, SP, Brasil. Ciência e Tecnologia de Alimentos, 19 : (3).

Neumann, R. M. and Ward, S. M. (1999), Bioaccumulation and biomagnification of mercury in two warm water fish communities. Journal of Freshwater Ecology, 14 : (4), 487-497.
Paz, L. A.; Alegría, A.; Barberá, R.; Farré, R. and Lagarda, M. J. (1997), Determination of mercury in dry-fish samples by microwave digestion and flow injection analysis system cold vapor atomic absorption spectrometry. Food Chemistry, 58 : (1), 169-172.

Pinho, A. P. (1998), Mercúrio total em elasmobrânquios e teleósteos da costa leste do Brasil. Tese (Doutorado), Universidade Federal do Rio de Janeiro. $94 \mathrm{pp}$.

Simpfendorfer, C. and Donohue, K. (1998), Keeping the fish in "fish and chips": research and management of the Western Australian shark fishery. Marine and Freshwater research, 49, 593-600.

Suzuki, Z.; Warashima, Y. and Kishida, M. (1977), The comparison of catches by regular and deep tuna longline gear in the western and central equatorial Pacific. Bull. Far Seas Fish. Res. Lab., 15: (51), 89.

Thompson, J. D. (1985), Mercury concentrations of the axial muscle tissue of some marine fishes of the continental shelf adjacent to Tasmania. Australian J. Marine and Freshwater Research, 36 : (4), 509-517.

Walker, T. I. (1976), Effects of species, sex, length and locality on the mercury content of School Shark Galeorhinus australis (Macleay) and Gummy Shark Mustelus antarcticus (Guenther) from south-eastern Australian waters. Australian Journal of Marine Freshwater Research, 27, 603-616.

Walker, T. I. (1988), Mercury concentration in edible tissues of elasmobranchs, teleosts, crustaceans and mollusks from south-eastern Australian waters. Australian J. Marine Freshwater Research, 39, 39-49.

Ward, S. M. and Neumann, R. M. (1999), Seasonal variations in concentrations of mercury in axial muscle tissue of Largemouth Bass. North American Journal of Fisheries Management, 19, 89-96.

Watling, R. J.; McClurg, T. P. and Stanton, R. C. (1981), Relation between mercury concentration and size in the Mako Shark. Bulletin of Environmental Contamination and Toxicology, 26, 352-358.

WHO (1989), Evaluation of certain food additives and contaminants. Thirtieth third report of the joint FAO/WHO expert committee on food additives, World Health Organization (WHO, Technical Report Series 776) Geneva. 80 pp.

Received: October 03, 2002; Revised: April 03, 2003; Accepted: February 02, 2004. 